\title{
The Economics Profession in Pakistan: A Historical Analysis
}

\author{
NADEEM UL HAQUE and MAHMOOD HASAN KHAN
}

\section{INSTITUTIONS, ORGANISATIONS, AND ECONOMIC DEVELOPMENT}

Economics is a policy science: its claim is to describe policies that can improve peoples' lives. Its usefulness for policymaking, therefore, depends on how well economists understand and interpret economic behaviour. In other words, successful economic policy entails a good understanding of the dynamics of economic change. In turn, a model of economic change requires analysis of institutions and organisations in the society. Institutions are the informal conventions (customs) and formal rules by which the members of a society organise the production and distribution of goods and services. Organisations are the players in the economy, including the state (executive, legislature and judiciary), private businesses (profit-seeking individuals and corporate entities), and private non-profit associations (NGOs, professional groups and bodies). Both institutions and organisations change with the evolution of each society and economy. Much as economists disagree on the underlying assumptions and interpretation of "facts" about economic change, they have a broad agreement that the discipline of economics must be embedded in the study of interactions between institutions and organisations.

A major factor in the development of Western Europe (including North America) since at least the seventeenth century was the realisation that knowledge, based on rational thought and empiricism, was valuable hence to be pursued to empower the self and society. It is with the application of this knowledge to natural resources that much capital has been accumulated and incomes increased. It is also true that the accumulation of knowledge and expansion of markets were

Nadeem Ul Haque is Adviser, Research Department, International Monetary Fund, Washington, D. C., Mahmood Hasan Khan is Professor in the Department of Economics, Simon Fraser University, Burnaby, B.C., Canada. 
accomplished by changes in institutions and organisations of the society. Both of these changes reinforced each other. The relative failures of the Chinese and Islamic societies can also be explained within this perspective. Modern colonial empires were sustained by the strength of capitalist institutions and the associated technology used in commerce and war. A vast majority of underdeveloped countries as colonial societies - devastated though their people and resources were in many respectshave inherited institutions and organisations implanted by the colonialists.

The literature on economic development since the end of World War II has made significant contribution to the economics discipline as the discipline itself has contributed to our understanding of how economies change and how do institutions and organisations play their roles in this process. A society first needs a legitimate state that the populace generally supports: it has achieved a consensus for governance to promote peace. It establishes a legal framework that clearly defines property rights, enacts laws and rules for contracts and maintains a rule of law. The judicial and administrative structure should have the capacity to enforce the laws and rules. The roles of organisations-the state, private businesses and non-profit entities (NGOs)-should dovetail their function without doctrinal rigidity. The state should (i) maintain a facilitating environment-including expansion of property rights and stable macroeconomic policies-for the other two organisations and (ii) invest in public and merit goods that the private sector may not produce or provide in optimum measure. Businesses (farms and firms) must play by the rules in the marketplace without reliance on public subsidy, open to competitive forces both internal and external. NGOs should help expand the base of civil society to ensure that the state and businesses do not injure the public interest. Of course, these roles evolve through time as experience accumulates, reflecting clearly the dynamics of economic development embedded in changes in technology and institutions.

\section{THE ECONOMICS PROFESSION AND ECONOMIC DEVELOPMENT}

For our purpose a profession can be defined as a group (body) of persons practising an occupation requiring intellectual abilities and training. Contemporary intellectual and professional specialisation is the result of the growth of accumulated knowledge in natural, physical and social sciences in the last four centuries. In addition, and perhaps more importantly, the growth and evolution of modern (complex) industrial society and economy have fostered the development of professions. The development of professions has in turn contributed to our understanding of how economies, societies and polities function and what works and what does not. The rise of the economics profession-a critical mass of influential people with specialised knowledge-can be traced to the emergence of modern 
industrial economy in the 19th century. Economists found their place not only in the academia teaching and doing research but advising private businesses engaged in finance and manufacturing and governments in their central banks, treasury, colonial and war offices. They established professional associations to exchange and publicise their ideas and results of researches through conferences, journals, pamphlets, and books. Peer recognition and institutional support became important to economists for their reputation and influence in the professional circle and society. Universities became the competitive reservoir of professionals-teachers and researchersproducing knowledge and young professionals carrying that knowledge to the rest of the society. The deepening of the economics profession, as of other professions, has been an integral part of the development and evolution of a corporate culture and civil society in the industrially advanced countries.

The economics profession has developed its strength and influence on public policy in the industrially advanced countries because of several factors. For one thing, it has generally been allowed an environment of free inquiry and public support through investment in the infrastructure necessary for acquiring and disseminating knowledge. Seekers and distributors of knowledge and ideas have been respected, recognised and adequately rewarded. Intellectual competition has induced creative ideas and use of the scientific method. Competing paradigmsclassical, neoclassical, Marxist, Keynesian, Monetarist-have developed according to differences in ideology and interpretation of events (facts). Economists have borrowed methods of inquiry from physical and natural sciences and adapted the language of logic and mathematics to test their hypotheses and theories. All of this allows the professionals to describe, explain, analyse and propose policy prescriptions: what works or does not work. Of course, given the complexity of issues related to human behaviour, there is much in economics that is controversial. Public sector investment in and support for education and research in economics and the growth of private sector institutions-financial and corporate sectors-have also been important factors in the development of the economics profession.

We cannot make similar generalisations for the economics profession in underdeveloped countries. For one thing, with some exceptions in Latin America, there was almost no economics profession in these countries before they achieved political independence as nation states after end of World War II. Almost all economists were employed in a limited number of colleges and universitiesengaged almost exclusively in undergraduate teaching-without any influence on policy-making since government policies were established by the Centre's political élite and private interest groups and carried out by colonial administrators. The demand for economists in the colonies was limited and met by the expatriate professionals and bureaucrats. A second problem was that training in economics did not equip individuals with concepts and methods necessary to make critical analyses 
of the received economic theory and interpretation of economic facts. Similarly, resources were not available to establish the infrastructure necessary to conduct economics research. Finally, the institutional environment was dominated by feudal and tribal social structures with a limited role of competitive markets for ideas, resources and products. The colonial governments did not much encourage (intellectual) competition in the colonies since it was thought to be potentially subversive. In fact, for most of the educated élite in underdeveloped countries-a vast majority of them belonged to the well-connected feudal, merchant or tribal families-the two professions with the highest pay-off were the government's administrative services and practice of law or politics.

The structural conditions in most underdeveloped countries after World War II were quite similar in that their economies were dominated by feudal (tribal) and mercantilist institutions. These countries also inherited a colonial political structure in which the only dominant player was a non-representative and highly centralised state with little or no accountability to the people it ruled. What is even more important is that the new political élite-to whom the colonial masters transferred power at independence-were deeply impressed by the idea that the state had a major (if not a central) role to promote economic development. In some cases it was ideological, but for many it was simply expedient. Their positions were greatly strengthened by the dominant development paradigm and competing sources of foreign economic assistance. The development paradigm most popular and influential at that time had at its core the idea that economic growth-capital accumulation and technological progress-required an activist state since private markets were weak, fragmented and unreliable. Foreign economic assistanceboth from multilateral and bilateral sources-was likewise premised on the assumption that the state must take the lead in directing the development process. Also, the economics profession was dominated by this idea due to the writings of John Maynard Keynes, Marxist ideology and the "socialist" experiment in the former Soviet Union, and a particular interpretation of historical growth in Japan and Western Europe. In many countries, a major consequence of all this was an uncritical reliance on the beneficent power of the state and foreign economic assistance.

\section{THE ECONOMICS PROFESSION IN PAKISTAN: BACKGROUND}

This case study offers us a unique perspective to understand the issue of the development of a profession, because at independence Pakistan inherited very few trained economists. Since independence numerous government and donor inspired efforts have been made to develop professional economists and the profession of economics. Our analysis focuses primarily on these efforts to see how a broad-based profession of economics can be developed in Pakistan. This study also has 
implications for govermments, foreign donors and other groups that seek to catalyse such developments in other underdeveloped countries. It is common knowledge that at independence in 1947 we did not inherit a large stock of professionals in any field. While the stock of professionals in several fields has increased quite significantly, we have not taken stock of professional development in Pakistan. There are no analyses available of any profession to see how we have developed from what we inherited. Such analysis is important to see whether the development of professions has been relatively healthy or not. It is in this spirit that we attempt to develop a history of the economics profession in Pakistan.

It is necessary first to layout the major institutional and structural conditions that Pakistan inherited at independence in 1947. First, Pakistan's economy was based mainly on agriculture with little industrial production: this region of the Indian economy was exporting food and raw material in exchange for manufactured (industrial) goods from other regions or abroad. Further, most of the commercial and industrial activities were controlled oy non-Muslim entrepreneurs who left Pakistan after the partition of India. Second, Pakistan's society was (a) dominated by primordial (feudal, tribal and caste) relations and (b) divided between the rich few and rural masses. Third, the political élite-who came mainly from the feudal families-exercised power through the state machinery in which the civil administration played a dominant role. Finally, the professional class was very small and without much influence: there were almost no professional societies or entities. Most of the professionals were working in the public sector organisations, including colleges and universities. The small educational system-with limited number of institutions, enrolments and faculty-was based on curricula that emphasised disciplines and skills needed to assist the colonial administration.

There were few economists in Pakistan, working in universities and colleges and the State Bank of Pakistan (SBP). There was no institution involved in applied economics research, except for the Punjab Board of Economic Inquiry and the Agriculture College in Lyallpur. It should, however, be added that the academic economists (from East and West Pakistan) established the Pakistan Economic Association in 1950, which started to publish its journal, Pakistan Economic Journal (PEJ), in the same year and held annual meetings until 1968. Many of the contributors to PEJ were well-known international economists and others were Pakistani academics (mainly from East Pakistan).

\section{THE FIRST TWENTY-FIVE YEARS: FROM INDEPENDENCE TO DISMEMBERMENT(1947-1971)}

In the first five to six years after independence, the federal government initiated two programmes for the development of professional economists to work mainly in the public sector. The State Bank of Pakistan initiated a programme 
whereby economists were attracted to the Bank as it offered a reasonably attractive professional career. Some of them were sent overseas for a $\mathrm{PhD}$ in economics. As Haq and Baqai (1988) note, "the first generation of economists in Pakistan was trained in the remarkable tradition of the State Bank of Pakistan". At the same time, the government established overseas training scholarships for young economists working in universities and the government. While some of the trained economists returned to Pakistan, but others joined international organisations to pursue their individual careers. No attempt was, however, made to encourage the college and university faculty to improve their knowledge or education. In fact, a high proportion of the university and college teachers were attracted to join the civil service of Pakistan to improve their well-being and social status in view of the growing influence and status of bureaucracy.

In the early to mid-1950s, two important developments initiated the growth of the economics profession Pakistan. First, there was rapid expansion of teaching institutions (universities and colleges) and government departments (e.g., State Bank of Pakistan, Central Statistical Office, and Planning Commission) that required trained economists. Second, foreign economic assistance started to provide the necessary resources to support local and foreign education and training. The Commonwealth and Colombo Plan were the first major multilateral sources of assistance, including scholarships for foreign education. However, in the second half of the 1950s, the United States official bilateral assistance-with additional support from the Asia Foundation, Ford Foundation, and U.S. Educational Foundationbecame the more important source of institutional support and individual training and educational scholarships. In fact, the first major crop of economists was harvested with the advent of American aid-under the Point-4 programme-and involvement of the Harvard Advisory Group (HAG) from Harvard University Centre for International Affairs in the affairs of Pakistan's economy in the mid-1950s. ${ }^{1}$

The active involvement of the United States in Pakistan's economic affairs was part of the Cold War alliances in which Pakistan became an active regional partner in the mid-1950s. With the rise of General Ayub Khan into power in 1958, the U.S.-Pakistan alliance was cemented and bilateral economic aid from the United States became a very important source of foreign resources for the "planned" development of Pakistan's economy. In fact, the First Five-Year Plan (1955-60)which was launched in 1957-became the foundation document articulating the official development strategy later endorsed and reinforced by Ayub Khan. The policy framework of the time envisioned an activist government to be led by the

'The term Harvard Advisory Group (HAG) has been used loosely in view of the fact that this group came to dominate economic policy and thinking in the country. In the early period, there were a number of U.S universities and funding agencies (Ford Foundation in particular) seeking to work with Pakistani institutions. 
modernising élite with benevolent sentiments for the well being of the population. All that was needed was to graft and develop economic expertise. It is in this context that the HAG advisors became influential in designing Pakistan's economic policy in the Ayub era (1958-68). In this they had strong support of the international aid community. Their vision for Pakistan also included a large infrastructure for the development of economics and economists in Pakistan. Primed by the desire to promote and catalyse rapid economic growth in Pakistan, the HAG thinking (perspective) underlying these institutions was to quickly develop some policy analysis units appended mainly to the government.

In line with this thinking, the HAG advisors strengthened the Planning Commission and, with assistance from the Ford Foundation, established the Pakistan Institute of Development Economics (PIDE) in 1957. In the following year, PIDE started publishing its. journal, Economic Digest, which was replaced by The Pakistan Development Review (PDR) in early 1961. The Directors of PIDE and Editors of PDR were Americans until the end of 1965. The first Pakistani Director of PIDE was appointed in early 1966-supported by HAG advisors-who remained in that position until the PIDE ended its work in Dhaka with the dismemberment of Pakistan in December 1971. Economic aid from the United States and the HAG advisors helped to equip the Planning Commission, State Bank of Pakistan and PIDE with some of our most economists-who have continued to loom large on the economics profession in Pakistan-in the 1950s and 1960s.

This trend culminated in the establishment of the fields of development studies and public administration that in any case were closely associated with the generalist education offered to the civil servants in the Civil Service Academy. Edward Mason at Harvard University, who had considerable influence on development studies and the U.S. aid programme, encouraged young Pakistani civil servants and others to acquire training in Public Administration from U.S. universities. The famous Edward Mason programme was set up in Harvard University-to award a Master in Public Administration (MPA) degree-to which senior and influential bureaucrats were sent and came back to dominate the economics profession. Because of their bureaucratic associations and the backing by donors these holders of MPA degree were quite important in the economics profession in Pakistan. In fact, this programme further margnalised the role of the academic institutions.

It is worth noting that very few economists were added to the academic institutions because of the relatively low economic and social status of universities and inadequate infrastructure for serious research. The academic economists in Pakistan started to appear in small number in the 1950s. However, the colleges and universities did not receive large-scale financial and institutional support to create a research-friendly environment. Further, the internal administrative structure in the Departments of Economics was highly hierarchical, giving almost uncontested power 
to the senior faculty who had not been exposed to economics research or inquiry. A few who returned from abroad in the late 1950s to mid-1960s did not survive and others resigned themselves to routine teaching. Consequently, there was no economist engaged in serious research in the academia. But that is not surprising given that academia was ignored and its management structure was almost feudal. Perhaps the only exception to this model was the Department of Economics at the Quaid-i-Azam University created in the late 1960s. But this too did not last for too long, thanks largely to the infighting among the faculty, and came to a sad end towards the end of the 1970s. Since then its record has been no better than other Departments of Economics in the country.

The HAG vision was flawed in three major respects and sowed the seeds of distorted development of economics profession in Pakistan. First, it did not attempt to develop an economics profession that was rooted in the country. The HAG economists left the universities and colleges in a state of neglect, using most of the domestic and foreign resources to build the largely non-academic, semi-bureaucratic institutions, and attempted to give these institutions the role of leadership in the profession. Without the seed of the profession being nurtured and jealously guarded in academia, the profession was bound to have distorted growth. Second, the HAGtrained economists were very deferent from the mainstream economists of the time in the West. The HAG-sponsored training was development-oriented and specific to Pakistan. They were not encouraged to do any theoretical or pioneering research. They were instead trained to assist policy-makers design plans and projects within the overall development vision of the time. Third, given the influence of HAG and the new institutions, and the symbiotic relationship between these institutions and the bureaucratic and political structure of the time in Pakistan, the HAG-trained economists acquired a large and visible role in the economy. These visible economists have not only played an important role in Pakistan's history, but also by and large distorted the perception of economist, the economics profession and economic policy in Pakistan.

To drive all these ideas home, let us contrast the Pakistani economists with the Indian economists of the time. First, all major Indian economists are rooted in their academic institutions, having taught at home and in major universities overseas. Second, they have engaged in theoretical and fundamental research, and not just development economics, and have published widely in major academic journals and not just on Indian economy. Third, they have had limited visibility in the corridors of power in India, other than through their international prominence. Interestingly, the Indian economics profession matured in the 1970 s in the sense that the domestic teaching and research institutions reached a level of self-perpetuation where its products are internationally recognised. The implicit proposition here is that had the HAG vision been based on rooting the profession on sound academic lines in 
academic institutions in the country, perhaps Pakistan would have seen a wholesome development of the profession.

Let us now turn to the dominant economic ideas planted by the HAG advisors in Pakistan. By design and reflecting the development thinking of the time, the HAG group was interventionist and oriented to plan and budgetary allocations. ${ }^{2}$ They largely mistrusted the market and arrogantly assumed (even claimed) that planners and bureaucrats had better (more) information than the market and the rest of society. ${ }^{3}$ Interestingly enough, the HAG training of development economics was collapsing on itself by the early 1970 s. Because these people had no behavioural relationships in mind and no faith in markets, they did not merely push policy levers and study response lags and dynamics. Instead, they developed lengthy plans or wish lists and used the bureaucratic structures to control the environment to make these plans happen. The control-oriented and market-mistrusting civil service loved this new intellectual force given to their view.

A second element in the thinking of the HAG economist was the increasing concern with poverty and inequality. Haq and Baqai (1986) note with concern that "early writing on economics in Pakistan surprisingly did not contain much reference to poverty related themes." It is interesting that most of the early econometric or behavioural research is done mainly by the HAG advisors, whereas the work on measuring poverty, productivity is done by the Pakistani economists. Before anything about the economy was understood, poverty and regional inequality indices, and decline in real wages (when the wage data were hardly available) were the main areas of concern as is reflected by articles in PDR.

The manner in which the first-generation economists were trained itself created a certain perception of economists in Pakistan. They were trained to be policy-oriented development economists. A sharp distinction was made between such economists and those who studied more theoretical and academic economics. The erroneous impression was unintendedly cultivated that the study of theory or more rigorous economics was of limited use to the country. Such pursuit was considered a luxury that the country could ill-afford. This view has persisted and developed over

${ }^{2}$ It is interesting to note that Haq and Baqai (1988) point to the "widening in the choice of subjects in research" in the 1960s and 1970s. Their choices include. "analysis of planning expertise"; "powerful question of regional disparity"; "question of dual exchange rate"; "effective protection"; type of industrialisation"; and the "effect of the tube wells on agriculture". They also note, somewhat disparagingly, that the "focus of economic literature in the fifties was on monetary analysis, fiscal policy, deficit financing and inflation". These statements illustrate our point that the issues of concern to the development economist in the 1960s and 1970s were interventionist and distributional and not those dealing with macroeconomic stability backed by a market-oriented regime.

${ }^{3}$ See Hussain (1988), who argues that "the logic of planning is that the existing set of world prices is not an appropriate indicator of resource allocation," and concludes that the "sixth five year plan constitutes an abandonment of.....planning in the strictest sense of the term....since it adopts world prices and comparative advantage as a basis for the abandonment of national economic planning". 
time and reinforced the perception that to be a good economist for Pakistan a grounding in economic theory is not only not required but perhaps may even be a hindrance. The result is that there is a tremendous disrespect for academic and theoretical economics. The term "ivory tower" intellectual has been used to describe anyone who attempts to read and keep abreast of academic economics. Instead, an amalgam of general knowledge and mild development verbiage has been established as sound Pakistani development economics.

\section{THE POST-BANGLADESH PERIOD (1972-1997)}

By the late 1960 s and early 1970 s, the HAG era was ending and fragmentation in the nascent economics profession was already visible. In the late 1960s, Bengali economists started to take lead in the academic field, but their major interest was to highlight the so-called interregional inequality and resource transfer. The West Pakistani economists were following the HAG design and were totally enmeshed with the civil service and the political scene in developing the annual budgets and fiveyear plans. The Bengalis felt marginalised from this and were heading off in the direction of laying the ideological and economic foundation for the emerging state of Bangladesh. The separate reports of the Bengali and West Pakistani economists for the Fourth Five-Year Plan (1970-75) remain perhaps the most important evidence of the contradictory visions of development in Pakistan. The State Bank group was frustrated by the relative lack of importance of the Bank and monetary policy and the domination of the Bank by the civil service. The possibility of an independent and professional Bank had apparently become more remote. Indeed the State Bank of Pakistan never developed a core economists given to serious research.

The academic and research environment for the economics profession in Pakistan started to change in the 1970s in several ways. First, Pakistan's dismemberment in 1971-splitting into what are Pakistan and Bangladesh now-had profound implications for the profession. The main institution for economic research, PIDE, was moved from Karachi to Dhaka in 1969 and the main economists who were running it were Bengalis. The result was that the Institute was virtually moribund. Second, even the Pakistani economists who remained were induced overseas by a combination of better incentives in international agencies. To this a feeling of devaluation of professional skills was added in the Bhutto era (1972-1977) which was dominated by the rhetoric of socialism accompanied by large-scale nationalisation of banks and industries. The visibility that professional economists had acquired in the Ayub era was lost by now. They had little to contribute to public policy during the 1970s and the Planning Commission lost its earlier importance.

By the early 1970s, the HAG-trained economists had been marginalised by the political movement led by Zulfikar Ali Bhutto, dominated by the ideas of 
nationalisation and socialism. Politicisation of the civil service further weakened the influence of professional economists in government services. However, after the imposition of Martial Law in 1977, the civil service was rehabilitated to its former dominance in policy-making. The political rhetoric of the militrat regime led by General Zia ul Haque shifted to a full-steam programme of "Islamisation" with a large doze of foreign aid. These changes fragmented the economics profession further. Some economists used their international development contacts to retreat to the international agencies where, as we all know, they have had sterling careers. At this stage, the first Pakistani academic economists also emerged not through the government or donor inspired scholarship schemes but through individual career choices. Some of them started publishing in overseas journals and occupied prestigious positions in universities and international organisations. However, given the dearth of academic institutions, incentives and academic respectability in Pakistan, all of them have stayed abroad. Attempts were made to compensate for these losses by means of some institution building.

\section{Building Research Institutions}

The PIDE was re-established in Islamabad in mid-1972, followed by the creation of Applied Economics Research Centre (AERC) as a "centre of excellence" in the University of Karachi. This eventually paved the way for several institutions for ostensible economic research. These institutions as they were formed received substantial financial assistance from the federal government, USAID and the Ford Foundation. A large number of young professionals from these institutions were sent overseas, particularly to the United State, for the Master and $\mathrm{PhD}$ degree programmes with financial assistance from one or another donor agency. Some economists from universities were also sponsored to complete M.A. and $\mathrm{PhD}$ degrees under different scholarship programmes. These institution-building efforts during the 1970 s and 1980s have not borne fruit as they were plagued by at least four major difficulties.

First, universities were not able to attract or keep the newly foreign trained economists for lack of favourable work environment-feudal management structure, poor research infrastructure (books, journals, computing facilities, etc.) and low material incentives. Some of these academics moved to public sector organisations or international organisations. There is not one Department of Economics in Pakistan today with a credible programme in economics. The academic quality of graduates at the M.A. level is by and large low and uneven between universities, and quite inferior to a middling B.A. in any international university. However, this reflects the larger national crisis in Pakistan's post-secondary education system.

Second, the PIDE-which was the supposed leader and a model of economic research-was also unable to attract and hold a core group of competent economists. 
The AERC, which has made a significant reputation for itself largely through its entrepreneurial leadership, too was unable to develop a significant grouping of economists. Both of these institutions had access to scholarships for several young economists to study mainly in the U.S. throughout the 1980s. It is important to note that PIDE and AERC, for more or less similar reasons, have lost several well-trained economists to public sector institutions and international agencies in the last decade.

Third, interestingly enough, throughout this period, the fragmentation of the profession mentioned earlier has persisted, reflecting the poor institutional development in Pakistan. Whether the HAG-trained economists, who went overseas, took no interest or were not allowed to work does not matter since the result is the same. The new professionals who never really worked in Pakistan attempted to do so, but have found that they cannot contribute or are used for purpose of internal institutional politics rather than professional or institutional development.

Finally, the visible fragmentation and institutional decline are further evidence in that the State Bank of Pakistan has stopped virtually all in-house research and its publications since the mid-1970s. Moreover, all of the research centres and institutes, including PIDE and AERC, have largely excluded from their programmes and studies the involvement of faculty from the Departments of Economics in universities in Karachi, Islamabad, Lahore, Peshawar, and Hyderabad. There is almost no formal joint study and research programme at any of these places. On the contrary, there is unhealthy competition for scarce resources and skills and even mutual resentment and hostility.

Considering the migration of skilled economists to overseas positions, the supply of quality economists in Pakistan has remained quite limited. Notwithstanding the limited skilled resourcès, the push for creating new "research" centres and institutes accelerated through the 1980s. Several new centres (institutes) were established during this period: the Centre for Applied Economics Studies in the University of Peshawar, Economics Research Centre in the University of Sindh, Punjab Economics Research Institute (formerly the Punjab Board of Economic Inquiry) in the (Government of) Punjab Planning Board, Institute of Development Studies in the Agriculture University in Peshawar, and Islamic Economics Research Centre in the International Islamic University in Islamabad. The available resources were spread too thin so that no core grouping of professionals has been formed anywhere.

It seems that there are two major reasons for this mushroom-like growth of the so-called research institutions: (i) build new regional or specialised capabilities for economic research as competing empires vis à vis Departments of Economics in universities and (ii) use them as institutional vehicles to attract projects and studies funded by governments and foreign donors. The proliferation of institutions was also accompanied by an increase in the number of universities in Pakistan. The traditional 
centres of learning in Pakistan, such as the Punjab University or Government College in Lahore, meanwhile were denuded of funding. The case of the Islamic Economics Research Centre is somewhat special in that the establishment of the International Islamic University coincided with the policy of Islamisation in the Zia era. Several relatively young economists were drawn into the teaching of and research on "Islamic Economics" in the International Islamic University. It is fair to say that most of the research centres and institutes have so far neither created a favourable environment for academic research nor published any research output. The result of all this has been to reinforce the notion established in the earlier period that the profession of economics was to be nurtured outside the university centres.

\section{Developing Professional Associations}

At the meta-institutional level, an effort was made to revive the Pakistan Economic Association (PEA) in mid-1972, which held its 16th-and as it turns out the last-Annual Meeting in Islamabad in early 1973. As stated earlier, PEA had held its annual conference from 1950 to 1968 and maintained its quarterly journal, PEJ, to which papers were contributed by some well known international scholars and academics that enjoyed respectability within academia. However, after its meeting in 1973, PEA went into a state of inaction from which it has not recovered to this day. The moribund state of PEA and its revival were discussed in several public fora in the late 1970s (University of Karachi) and early 1980s (University of Punjab), but without results. PEA was effectively controlled by a small number of senior (academic) economists, and its last president did not hold the usual annual meeting for a number of years.

As an alternative to the defunct PEA, PIDE established the Pakistan Society of Development Economists (PSDE) in 1983. PSDE was established as an instrument of PIDE for its own purposes and not necessarily for the development of the profession. Its membership was not open. Professional associations normally select the president on the basis of intellectual stature and for a limited tenure, usually a year. An important function of the president is to conduct some key proceedings of the association to further his/her scholarly agenda. That is how a professional association remains alive and gets invigorated. Contrary to this standard professional practice, the Director of PIDE is also appointed the president of PSDE under its charter. PSDE activities have, therefore, highlighted the personal agenda of the Director of PIDE. The annual meetings of PSDE have usually attracted some international economists (funded by foreign assistance from Germany and the Ford Foundation endowment fund) and some Pakistani economists from outside PIDE. But these PSDE annual meetings are perhaps more distinguished by the prominent Pakistani economists that were often excluded from participation. 
Considering the checkered life of the PEA and activities of PSDE so far, it is clear that Pakistani economists have been unable to create a forum that would disseminate economic thought and ideas and subject all shades and hierarchies of the profession to peer opinion and discussion. Indeed this failure has been an important reason for the stunted development of the profession. The key question for future is to lay the foundation of a professional association in the environment where hierarchies and titles are less important then exchange of ideas through open debate and discussion under the critical scrutiny of one's peers in the profession.

\section{Research and Professional Journals}

A detailed evaluation of research output from PIDE and AERC - the only relatively active research institutions in the country-in the last 15 years is hard to make, thanks to lack of detailed information about their research programmes and research output. However, some meaningful comments can be made on the basis of published articles in PDR and PJAE and occasional papers and reports issued by PIDE and AERC. ${ }^{4}$

The PIDE research programme seems to cover a variety of issues or themes, driven mainly by their "relevance" to Pakistan, availability of funds and research staff. The research areas range from demography (population and migration) to industry (productivity and protection), agriculture (terms of trade, use of inputs, farm productivity), and monetary and fiscal economics (money demand, government spending, inflation). Articles published in PDR are contributed both by the research staff of PIDE and outside contributors. Some of these articles are products of project or programme-based reports prepared by the PIDE staff for the government and/or international donor organisations. Other articles are of some academic standing, based on doctoral dissertations of the PIDE staff and other contributors. A large volume of the papers published in PDR are presented at the annual meeting of PSDE, for which they are not even internally screened much less refereed. It is worth noting that a high proportion of the PIDE papers are co-authored, reflecting "team work", but usually carrying the name of a senior economist in PIDE.

In 1982, AERC started its own biannual journal, Pakistan Journal of Applied Economics (PJAE), to publish the results of in-house research and contributions by outsiders. Looking at the issues of PJAE and AERC occasional reports, it seems that much of the in-house research has been driven by contractual project studies

${ }^{4} \mathrm{PJAE}$ and PDR are the main economic journals in Pakistan. Like the proliferation of "research" centres or institutes, a number of in-house journals, periodicals and magazines of uneven quality are issued by small colleges and departments of economics. They usually reflect vanity publication efforts. Also, it may be added that economic journalism in Pakistan has also increased, but it is still weak and uneven in quality. Perhaps only one weekly magazine, Pakistan and Gulf Economist, has achieved a respectable status in recent years. 
completed for governments, public sector agencies and international donors. The contractual "research" studies completed by the AERC staff reflect a limited number of areas: crop production, farm credit, local administration, urban growth, education and employment, and fiscal federalism. It is worth noting that the PJAE editorial staff are unable to publish the journal regularly even two times in the year: the time-lag has increased from one to two years.

Both PIDE and AERC seem to have very little to offer in their research programmes on the topical issues since Pakistan, like so many underdeveloped countries, has been slipping in or out of structural adjustment programmes since the early 1980s: For example, they have not examined the micro and macro aspects of the structural adjustment programmes, e.g., distorted markets for products and resources (land, labour and capital); effects of taxes and subsides on private sector efficiency, consumption and savings; financial repression; trade liberalisation; privatisation, etc. Despite the exhibited vulnerability of the country to repeated supply shocks to its main export, cotton and its products, none of these two institutions has had anything to say on the issue. It seems that expensive projects with dubious payoffs or esoteric value have received extensive patronage without any input from external referees or peer review. Also, there are very few examinations of the important social and economic questions of the time: quality of governance, fiscal federalism, regional resource transfer and income disparities, and the declining quality of life in the country.

\section{Academic Management and Incentive Structure}

The major factors affecting the volume and quality of academic research in economics include: the internal management structure, work environment, and the reward system in academia and research institutes. Reflecting the pathology of the larger feudal-bureaucratic social order in Pakistan, the senior management generally follows the national model of centralised power without consultation and participation. A high proportion of the junior research and teaching staff finds itself in a patron-client relationship, in which the patron has considerable power to punish and reward individuals. The personalised nature of power breeds mediocrity since salary, scholarship, and promotion are rarely based on merit and personal achievement. Some of the senior research staff and faculty have achieved their positions through this system and suffer from a sense of insecurity.

Rather than publication and the development of academic ideas, status and title are considered worthy if merit. For example, a PhD certificate has been regarded by many seniors academics and professionals as the end of their scholarship and research. They, therefore, set an example that young professionals are expected not to 
transgress if they want to build their careers. ${ }^{5}$ Often, in the academic and teaching institutions, one finds that the volume and quality of research published by the senior research staff are indeed very limited. In addition, it is rare to see the names of Pakistani economists in local universities and research institutes as authors of paper in journals outside Pakistan.

It is worth noting that universities, including Departments of Economics and Centres of Excellence (like AERC), have enjoyed a large degree of autonomy in their management since they are not governed directly by federal or provincial governments. They receive their funding through the Universities Grants Commission (UGC). This, however, does not mean that are entirely free from government interference since public sector representative carry substantial weight in the Board of Governors, etc. As stated earlier, the internal management structures are by large non-participatory, based on hierarchy by seniority. The reward system follows the national model of patronage. Finally, in the early 1970s, academics and professionals misguidedly fought for and received the national grade (and salary) structure followed in the civil service. However, they have not enjoyed the perks and rentseeking opportunities available to civil servants. Salaries for most academic and professional economists are quite unrelated to one's work and needs, leading to increased dependence on "moonlighting" or the more lucrative private consultancy work.

It terms of management, the case of PIDE is special since it was established as an "autonomous" entity in the federal government. Its Board of Directors is chaired by the Federal Finance Minister and includes secretaries of the Ministries of Finance, Economic Affairs, Planning, and Education. Other members of the Board are Governor of the State Bank, Chairmen of UGS, five members of the Council of Senior Fellows of PIDE. The Director of PIDE is ex-officio member of the Board. The Board Chairman enjoys substantial power because of his/her official position. The Council of Senior Fellows, with 15 members includes representatives from regional universities and professionals selected by the Director of PIDE. In theory, the Council supervises the research, training, publication, and professional functions of PIDE. In reality, the Council members act as "friends" of PIDE and often rubber stamp the Director's programme or agenda.

\section{Resources for Research: Aid and Consultancy}

There is little funding for economic research in the country, reflecting the general lack of investment in education and research in Pakistan. An academic has

s'In fact, a larger social problem in Pakistan, especially among the "intellectual" (technocratic) élite, is that the $\mathrm{PhD}$. degree grants the individual the right to add " $\mathrm{Dr}$ " as a prefix to his/her name, it simply acts as a status symbol and gives membership to the exclusive club. 
no way of finding funds for what he/she or his/her peer group might consider interesting or necessary for research. The only funding available is that which donors consider necessary for their operations. But then this funding is available to meet the priorities of lenders or donors and not to conform to the needs of the local community of economists. The donor agenda in Pakistan, as in many other countries, has not been consistent over time, since it has changed according to the shifting development perspectives of the political élite in the donor countries and senior managers of donor agencies. Similarly, donor funding has been unreliable, dependent largely on the changing priorities and moods of those in power in the donor countries and agencies.

A new and somewhat ominous phenomenon started to emerge in the early 1980s: careers in the consultancy industry. It has affected the economics profession in a disastrous way in Pakistan. Consulting on economic issues at the individual and institutional level is clearly associated with the growth of project and programmebased foreign "aid" from multilateral (e.g., World Bank and Asian Development Bank) and bilateral (e.g., United States, Japan, the European Union countries, Switzerland, and Canada) donors. Pakistan's dependence on foreign aid and its foreign debt liability have increased significantly in the last 15 years or so, hence increased involvement of the multilateral and bilateral donors. A major effect of donor involvement and inflow of resources for projects and programmes, mainly in the public sector, has been the growth of demand for local consultants (individual and institutional) as partners with foreign consultants or as independents to produce (feasibility and evaluation) reports on projects and programmes.

Consultancy has become a profitable industry for professional economists inside and outside universities and research institutes. Given the largely unfavourable environment for academic research in economics and the lucrative monetary gain and social status from consulting services, this industry has drawn the energy and time of almost every academic economist in the country. In fact, most of the so-called research agenda and output in almost all of the academia and institutes is driven by the demand for studies and reports by donor agencies and government departments or organisations. Coincidentally there has been impressive growth of NonGovernmental Organisations (NGOs) throughout the country, again based largely on foreign resources. ${ }^{6}$ The NGOs, working in the economic and social sectors, have been able to attract many economists to work for them. Almost all of this work has no serious academic or research content-in fact it is anti-intellectual since it wants immediate answers to self-serving propositions or questions-but its pecuniary benefits are generally much higher than in academia and provides greater exposure to

${ }^{6}$ The question, whether an appropriate domestic research or policy agenda can be formulated when the local academics and professionals depend so much on donor funds, is open to investigation. See Samad (1993). 
the wheels of power. The economists involved in consulting-and all of them arehave found a symbiotic relationship with the civil bureaucracy in Pakistan and officials of donor agencies. They need each other for their survival and growth. It seems that the economics profession is too well caught in this privately profitable but non-academic enterprise. Can it be saved from this malaise? It is hard to say at this stage.

\section{CONCLUSION}

Today there are very few Pakistani economists who have really seriously published and achieved a modicum of respectability in the academic world. They are to be contrasted with the HAG tradition in Pakistan of acquiring a doctorate and then doing high profile and catchy things in newspapers and magazines in Pakistan. Sadly enough some younger economists are continuing that tradition and they use every means at their disposal to decry the profession that they practice by making claims like "much of it may not be applicable," and "theory is only for advanced societies". Suffice to say that the old HAG divide continues!

To gauge the extent of the fragmentation in the profession, we recently conducted two simple investigations in Pakistan.

First, we surveyed the younger professionals to find out what sort of contact they had had with their more senior counterparts, especially the first crop of Pakistani economists. The answer was uniformly "no professional contact". In addition, many of them also said that, if ever they met, the first crop either patronised them or found some innuendo to deride them (e.g., "when are you going to get off your ivory tower and do some real work"). None of them felt comfortable with the contact noting that the first crop claimed hierarchical privilege and felt very uncomfortable with an equal debate of issues. The culture of Pakistan too does not help here, for age can often interpret a genuine difference of opinion as rudeness. This claim has often prevented dialogue.

Second, in looking at the development of professions and professionals in more advanced societies, we see that much of skill transfer takes place through mentoring by senior professionals of junior professionals (apprentices). All the younger economists denied that they had received any mentoring from their more senior professionals. In fact, many of them found the first crop to be unapproachable. More interestingly, upon searching, we could not find any professionals that the first crop had mentored.

The avalanche of economics consultancy since the early 1980s has exacerbated the plight of the young professional in Pakistan. Pakistani economists, instead of attempting to create their own professional associations, develop peer review and evaluation, and set their own research and policy priorities, are investing their major efforts into finding ways to please donors and to compete not often and 
only on the basis of professional competence but for the favour of the donor.

The building of an edifice on weak foundations is extremely difficult. Unfortunately, Pakistan did not inherit a tradition of learning and research. That in itself was a difficult obstacle to overcome. But it was capped by the advent of ideas from the donor development expert that did not root the academic profession in the cradle-the academic institutions-that would regenerate it. Instead, they created the visible, development economist of Pakistan. These development economists have been seeking a political role and have contributed nothing to the development of the economics profession in Pakistan. They have always displayed and impatience for growth and development. It is not surprising that they have missed out on the fundamental truth in theoretical economics that economic development is not mere "plan allocations" but human skill development. After all they have no respect for the "ivory tower" intellectual. The problem of academic study of economics and the development of professionals in Pakistan has become even more serious in recent years in light of the decline in the standard of education in the academia and the growth of consultancy and NGO industry. If only all Pakistani professionals will seek to develop deep and broad professions in their own respective fields, meaningful development can and will occur. Economic development will be the sum total (and may be even more) of the development of these professions.

\section{REFERENCES}

Ben-Ner, Avner, and Louis Putterman (eds) (1998) Economics, Values, and Organisation. Cambridge: Cambridge University Press.

Haq, Mahbubul, and Menadione Baqai (eds) (1986) Employment, Distribution and Basic Needs in Pakistan: Essays in Honour of Jawaid Azfar. Lahore: Progressive Publishers.

Haque, Nadeem Ul (1992) Economists and the Role of Government. Pakistan and Gulf Economist.

Hussain, Akmal (1988) Strategic Issues in Pakistan's Economic Policy. Lahore: Progressive Publishers.

Islam, Nurul (1981) Foreign Trade and Economic Controls in Development: The Case of United Pakistan. New Haven: Yale University Press.

Kardar, Shahid (1987) Political Economy of Pakistan. Lahore: Pakistan Progressive Publishers.

Naqvi, Zafar J. (1993) Directory of Pakistani Economists and Demographers. Islamabad: Pakistan Institute of Development Economics.

North, Douglas C. (1990) Institutions, Institutional Change and Economic Performance. Cambridge: Cambridge University Press.

North, Douglas C. (1994) Economic Performance Through Time. American 
Economic Review 84:3.

Pakistan Institute of Development Economics (1993) Pakistan Institute of Development Economics: An Introduction. Islamabad: Pakistan Institute of Development Economics.

Pakistan Institute of Development Economics (1993) PIDE's Research Programme for 1993-1996. Islamabad: Pakistan Institute of Development Economics.

Robinson; E. A. G. (1967) The Problems of Teaching Economics in Pakistan. Karachi: Pakistan Institute of Development Economics.

Samad, Abdus (1993) Governance, Economic Policy and Reform in Pakistan. Lahore: Vanguard Books.

Siddiqui, Akhtar H. (Various Issues) The Economy of Pakistan: A Select Bibliography. Islamabad: Pakistan Institute of Development Economics.

Williamson, Oliver E. (1994) The Institutions and Governance of Economic Development and Reform. World Bank Economic Review, Proceedings of the World Bank Annual Conference on Development Economics. 


\section{Comments}

The study analyses the development of economic profession over time and comes out with the conclusion that Pakistani economists have contributed very little to economic literature and to policy formulation in Pakistan. The study examines the role of universities, academic institutions, bureaucracy and the professional bodies in pre-and post 1971 period. The paper argues that lack of free inquiry and public support through investment in the infrastructure necessary for acquiring and disseminating knowledge on the one hand and the low research funds and the low reward structure for the economists have been responsible for that.

It needs to be underscored that a country needs three types of economists, viz. academics in the universities, professionals in the applied economic research institutes, and those in the government helping in the policy formulation. The major thrust of the study has been only on the first category. Times and again the study points out to relatively little contribution made by economists to the theoretical constructs while the Indian economists have been able to do so. Needless to add that most of the contribution made by the Indian economists is by those residing outside the country. Why celebrated Pakistani economists, both the authors are residing outside the country, have not been able to make similar contribution. After all expatriate Pakistanis enjoy the same facilities as their counterparts from other countries have. This has not been analysed in the paper.

The authors examine the role of Harvard Advisory Group in the training of Pakistani economists. The author points out that the training was imparted to bureaucracy but they do not seem to be happy over that. But if such training did result in better policy formulation what is the worry. When the group was not mandated to train the academicians why blame them. It is odd to note that the authors suggest that the Harvard group and the economists working in the government at that time did not believe in the market forces. One may look at the articles published in The Pakistan Development Review, the books published by those in the Harvard group and those in the Planning Commission and that should be sufficient to contradict the impression created by the authors. It needs to be noted that under their influence Pakistan abandoned the policy of controls and relied on price mechanism. The author gives an impression as if Harvard Advisory Group and the economists at that time were concerned with poverty. One wished they were. Unfortunately at that time the policy prescription favoured growth rather than income distribution leading to various problems by the end of the 70s. No doubt the economists trained at that time believed in the government intervention in the market. When there are distortions in the market the policy still merits consideration. 
The authors argue that government did not make any effort to upgrade the faculty of the universities and the academic institutes notwithstanding the fact that government did launch various programmes to do so. Unfortunately the influential persons got the fellowship but opted to stay abroad rather than serving the country. That they stayed away because in Pakistan they did not have the research grant and salary structure was poor may have some merit but considering that the Indian salary structure and the research grants have been no better than Pakistan the argument is not very valid. However, the observation that there has been no tradition to carry out research in the universities is probably right though recently even that is changing.

Why the economist in the government could not make contribution to the policies of the government? The economists are generally subservient to the bureaucrats in the government and their impact on policy-making is, therefore, limited. Over the passage of time they tend to forget the hard core economics and become bureaucrat in their own right. Their policy suggestions are not much different form an ordinary bureaucrat.

The Planning Commission was an effective institution in the pre-1971 period but in the post-197 period it has lost the significance. We may note that 197177 period was non-plan period and the Planning Commission did not have any Deputy Chairman. The Commission became only an institution to appraise the projects. The policy advice was neither sought nor planning commission volunteered. With increasing role of IMF and with their focus on short term issues like budgetary deficit and stabilisation the ministry of finance has taken up the role assigned to Planning Commission.

The authors examine the professional institutes like PIDE and AERC in detail. The Governing Board and Council of Senior Fellows of these institutions are examined. It is unfortunate that the authors come out with assertions without substantiating them. While in the earlier part of the paper the low salary structure is lamented at a later stage supplementing the salaries with consultancies is criticised. While too much of consultancy resulting into poor performance of the institutions is bad, the consultancies that help individuals and the organisation need to be encouraged.

The authors start with that it is a case study and as such one expected that it would come out with the suggestions for improvements in the profession. Unfortunately the study is completely silent on policy recommendations. Therefore the study at best is an analysis of the past experience relating to the economic profession in Pakistan but without leading us anywhere.

The Planning Commission, A. R. Kemal Government of Pakistan, Islamabad. 